Situs Jurnal : $\underline{\text { http://ejurnal.stiepancasetia.ac.id/index.php/jieb }}$

Jilid 4 Nomor 2 Juli 2018

Hal 288 - 300

\title{
PENGARUH KEPERCAYAAN, TANGGUNGJAWAB, DAN SIKAP TERHADAP KEPUASAN MASYARAKAT UNIT PEMBINAAN MASYARAKAT POLSEK DUSUN TIMUR KABUPATEN BARITO TIMUR
}

\begin{abstract}
Susilowati*
Abstract: This study aims to determine the significant effect simultaneously and partially variable belief, responsibility and attitude towards community satisfaction in Society Counseling Unit on Dusun Timur Police station. This research is a quantitative research. Sampling in this study was conducted by census technique. This technique is used because all the population is taken into the sample, considering the samples taken from 25 villages and one kelurahan each 3 people namely the Village Head (1 person), Village head assistant (1 person) and Chairman of the Village Consultative Board. The result of the research shows that partially, belief and responsibility are not significantly influence community satisfaction, where only the attitude has significant effect to the community satisfaction. Simultaneously all the variables have an effect on to the satisfaction of so community satisfaction in Society Counseling Unit on Dusun Timur Police station
\end{abstract}

Keywords: trust, responsibility, attitude, community satisfaction

Abstrak: Penelitian ini bertujuan untuk mengetahui pengaruh signifikan secara simultan maupun parsial variabel kepercayaan, tanggungjawab dan sikap terhadap kepuasan masyarakat Unit Pembinaan Masyarakat Polsek Dusun Timur. Penelitian ini bersifat kuantitatif. Pengambilan sampel dalam penelitian ini dilakukan dengan teknik sensus. Teknik ini digunakan karena semua populasi diambil menjadi sampel, mengingat sampel yang diambil dari 25 Desa dan satu kelurahan masing-masing 3 orang yaitu Kepala Desa (1 orang), Sekdes (1 orang) dan Ketua Badan Permusyawaratan Desa (BPD). Hasil penelitian menunjukkan bahwa secara secara parsial kepercayaan dan tanggung Jawab tidak berpengaruh signifikan terhadap kepuasan masyarakat, dimana hanya sikap yang berpengaruh signifikan terhadap kepuasan masyarakat. Secara simultan semua variabel berpengaruh terhadap kepuasan masyarakat pada Unit Pembinaan Masyarakat Polsek Dusun Timur.

Kata kunci : kepercayaan, tanggungjawab, sikap, kepuasan masyarakat

\section{Latar Belakang}

Dalam menjalankan fungsi pelayanan Polri dihadapkan pada masyarakat yang memiliki kebutuhan dan kepentingan yang berbeda atas jasa layanan publik. Dengan munculnya berbagai tuntutan masyarakat yang menginginkan pelayanan dengan kualitas yang baik terhadap kebutuhan terutama rasa aman. Suatu pelayanan publik dikatakan berkualitas apabila pelayanan tersebut mampu memberikan kepuasan kepada masyarakat yang menerima pelayanan tersebut karena pada dasarnya suatu pernyataan kualitas dalam pelayanan akan selalu terkait dengan pelayanan yang terbaik, yakni bagaimana para karyawan atau pegawai dalam melakukan atau melayani masyarakat secara baik dan memuaskan. 
Pelayanan dikatakan memuaskan apabila pelayanan tersebut dapat memenuhi harapan para pelanggannya. Kemudian suatu kualitas atas jasa dinilai oleh para pelanggan atau persepsi mereka,seperti pendapat yang dikemukan oleh Kot-ler (2005:42), yang menyatakan bahwa "kualitas harus dimulai dari kebutuhan pelanggan",yang artinya bahwa citra kualitas yang baikbukanlah berdasarkan sudut pandang atau persepsi pihak penyedia jasa, melainkan berdasarkan sudut pandang atau persepsi pelanggan.Jadi pelanggan yang mengkonsumsi dan menikmati jasa perusahaan sehingga merekalah yang seharusnya menentukan kualitas jasa.

Lembaga profesi yang melayani kepentingan masyarakat, Kepolisian Sektor (Polsek) dituntut mampu melaksanakan tugasnya sesuai ketentuan perundang-undangan maupun standar operasional prosedur (SOP) serta memiliki Etika Profesi dalam memberikan pelayanan kepada masyarakat.Di samping itu sikap mental dan disiplin kerja dari setiap anggota Kepolisian Sektor (Polsek), harus terus dibina dan dipelihara agar produk-produk pelayanan senantiasa sesuai dengan standar profesi Polri dan harapan masyarakat. Begitu pula halnya menyangkut dengan daya tanggap para petugas kurang respon yang baik dari petugas mengenai masalah yang dihadapi masyarakat mengakibatkan ketidak puasan yang dirasakan masyarakat.Kepolisian Sektor (Polsek) Dusun Timur dituntut harus dapat menyelesaikannya dan harus mampu menampung segala permasalahan dan beban yang dihadapi oleh masyarakat.Hal ini membuktikan bahwa betapa besar harapan dan kepercayaan masyarakat terhadap keberadaan Institusi Polri khususnya Kepolisian Sektor (Polsek) Dusun Timur tersebut namun harapan dan kepercayaan tersebut tidak akan terwujud apabila tidak diimbangi dengan perbaikan-perbaikan di internal Polri itu sendiri.

Berdasarkan Keputusan Kapolri No. : Kep/366/VI/2010 tanggal 14 Juni 2010 tentang Organisasi dan Tata Kerja Kepolisian Negara Republik Indonesia Resort (Polres), Bhabinkamtibmas merupakan anggota dari unit Binmas Polres dan Polsek. Unit Binmas adalah unsur pelaksana tugas pokok polsek yang berada dibawah Kapolsek.Unit Binmas bertugas menyelenggarakan pembinaan masyarakat yang meliputi pembinaan teknis Polmas dan kerjasama dengan instansi pemerintah/Lemabaga/Organisasi Masyarakat, pembinaan bentuk-bentuk pengamanan swakarsa serta pembinaan keamanan dan ketertiban masyarakat dalam rangka memperdayakan upaya pencegahan masyarakat terhadap kejahatan serta meningkatkan hubungan sinergitas Polri masyarakat. Unit Binmas dipimpin oleh Kanit Binmas yang bertanggungjawab kepada Kapolsek dan dalam pelaksanaan tugas sehari-hari di bawah kendali Kapolsek. Diperbarui 2015, Pada 26 Mei 2015, Kapolri Badrodin Haiti mencabut peraturan lama tentang Polmas, dan menerbitkan Peraturan Kapolri baru Nomor 3 tahun 2015 tentang Permolisian Masyarakat. Peraturan ini mengadopsi model Polmas di negara lain seperti Koban dan Chuzaiso (Jepang), Neighbourhood Watch (Inggris) hingga konsep Polmas di Selandia Baru dan Australia. Peraturan Kapolri Nomor 3/2015 menyebutkan Permolisian Masyarakat (Community Policing) atau Polmas merupakan kegiatan untuk mengajak masyarakat melalui kemitraan anggota Polri dan masyarakat, sehingga mendeteksi dan mengidentifikasi permasalahan Keamanan dan Ketertiban Masyarakat (Kamtibmas) di lingkungan serta menemukan pemecahan masalahnya.

Strategi Polmas adalah dengan mengikutsertakan masyarakat, pemerintah dan pihak lain dalam menangkal, mencegah hingga menanggulangi masalah keamanan secara kemitraan yang setara dengan Polri. Termasuk dengan mendatangi rumah ke rumah warga (door to door) di masing-masing wilayah penugasan.

Dalam pelaksanaannya, konsep Polmas menggunakan sejumlah prinsip seperti komunikasi intensif, kesetaraan dan kemitraan, transparansi dan akuntabilitas, partisipasi, menggunakan pendekatan personal/pribadi ketimbang formal atau birokratis, serta sikap proaktif dan lain-lain. 
Pelayanan Kamtibmas oleh Bhabinkamtibmas Polsek Dusun Timur masih belum maksimal karena masih terdapat beberapa indicator keberhasilan Polmas yang belum terpenuhi, yaitu:

1. Berdasarkan data gangguan Kamtibmas Polsek Dusun Timur Kabupaten Barito Timur tahun 2015 -2017, diketahui bahwa cukup sering terjadi peningkatan pada kasus pencurian sepeda motor di wilayah hukum Polsek Dusun Timur sehingga menimbulkan perasaan kawatir pada warga masyarakat yang meninggalkan kendaraannya (parkir), Pencurian di toko atau rumah warga, pemakaian shabu dan obat terlarang, senjata tajam, Perselingkuhan dan sengketa lahan.

2. Belum pernah dilakukan penelitian tentang Pengaruh Kepercayaan, Tanggungjawab, dan Sikap Terhadap Kepuasan Masyarakat unit Pembinaan Masyarakat Polsek Dusun Timur Kabupaten Barito Timur.

Kendala yang dihadapi oleh Kepolisian Sektor (Polsek) Dusun Timur itu dikarenakan antara lain :

1. Jumlah Personil yang minim. Berdasarkan Peraturan Kapolri nomor 23 tahun 2010 dijelaskan bahwa type Polsek Dusun Timur adalah Tipe Rural dengan jumlah Personel sebanyak 50 orang namun secara real baru dapat dipenuhi 22 Orang (44\%),

2. Kurangnya sarana dan prasarana penunjang kegiatan Operasional terutama kendaraan roda 4 (empat).

3. Jangkauan luas wilayah dan jumlah penduduk jika dibandingkan jumlah personel. Permasalahan dan kendala di atas, mengakibatkan kurang maksimalnya pelayanan terhadap masyarakat. Meskipun berbagai upaya telah dilakukan oleh Kepolisian sektor Dusun Timur untuk mengatasi hal tersebut akan tetapi tetap saja hasilnya tidak maksimal.

Mengingat bahwa Babinkamtibmas merupakan pelayan Kamtibmas yang berperan dalam mewujudkan Visi Polri yaitu pelayanan Kamtibmas prima serta terjalinnya sinergi polisional yang proaktif menyediakan pelayanan public yang harus mematuhi standar umum agar pengguna jasa memperoleh kepuasan (satisfaction), sehingga kualitas pelayanannya perlu dikembangkan agar menjadi lebih baik.

Berdasarkan pada latar belakang yang telah dikemukakan, dapat dirumuskan tujuan dari penelitian ini. Oleh karena itu, tujuan yang ingin dicapai melalui penelitian ini adalah :

1. Untuk menganalisis pengaruh secara parsial Kepercayaan, Tanggungjawab dan Sikap Terhadap Kepuasan Masyarakat Unit Pembinaan Masyarakat Polsek Dusun Timur Kabupaten Barito Timur.

2. Untuk menganalisis pengaruh secara simultan Kepercayaan, Tanggungjawab dan Sikap Terhadap Kepuasan Masyarakat Unit Pembinaan Masyarakat Polsek Dusun Timur Kabupaten Barito Timur.

3. Untuk menganalisis pengaruh yang paling dominan antara variabel Kepercayaan, Tanggungjawab dan Sikap Terhadap Kepuasan Masyarakat Unit Pembinaan Masyarakat Polsek Dusun Timur Kabupaten Barito Timur.

\section{Kajian Literatur}

Polmas adalah penyelenggaraan tugas kepolisian yang mendasari pada pemahaman bahwa untuk menciptakan kondisi aman dan tertib tidak mungkin dilakukan oleh Polri sepihak sebagai subyek dan masyarakat sebagai obyek, melainkan harus dilakukan bersama oleh polisi dan melalui kemitraan polisi dan warga masyaraka, sehingga secara bersama-sama mampu mendeteksi gejala yang dapat menimbulkan permasalahan di masyarakat, mampu mendapatkan solusi untuk mengantisipasi permasalahannya dan mampu memelihara keamanan serta ketertiban di lingkungannya. 
Tugas Pokok Babinkamtibmas di tingkat desa/Kelurahan sebagaimana diatur dalam Buku Petunjuk Lapangan No.Pol BUJUKLAP/17/VII/1997.yang ditanda tangani Kapolri tanggal 18 Juli 1997 adalah:

1. Membimbing masyarakat bagi terciptanya kondisi yang menguntungkan upaya penertiban dan penegakan hukum, upaya perlindungan dan pelayanan masyarakat di Desa/Kelurahan.

2. Sesuai dengan rumusan tugas pokoknya maka lingkup tugas Babinkamtibmas meliputi :

a. Membina kesadaran hukum masyarakat Desa/Kelurahan tentang Kedudukan, tugas wewenang, fungsi dan peranan polri, sangsi-sangsi pidana dan proses pemidanaan.Hak dan kewajiban warga masyarakat dalam penegakan hukum.

b. Membina kesadaran Kamtibmas Desa/kelurahan tentang:

- Masalah-masalah Kamtibmas.

- Sebab-sebab timbulnya gangguan Kamtibmas.

- Cara-cara penanggulangannya.

- Cara-cara penyelenggaraan siskamling pemukiman.

3. Membina partisipasi masyarakat dalam rangka pembinaan Kamtibmas secara Swakarsa di Desa/Kelurahan.

4. Sebagai polisi di tengah-tengah masyarakat Babinkamtibmas juga melakukan tugas-tugas kepolisian umum dalam hal-hal tertentu sesuai dengan sikon setempat yaitu :

a. Mengumpulkan bahan keterangan.

b. Mengamankan kegiatan-kegiatan masyarakat.

c. Menerima laporan pengaduan masyarakat.

d. Memberi bantuan pengawalan, pencarian dan pertolongan kepada masyarakat.

e. Membina tertib lalu lintas.

f. Penanganan tingkat pertama kejahatan, pelanggaran atau kecelakaan di TKP.

g. Melaksanakan tugas-tugas dibidang pembangunan atau kegiatan kemasyarakat berdasarkan permintaan instansi yang berwenang dan masyarakat setempat.

Tujuan Polmas adalah terwujudnya kemitraan polisi dan masyarakat yang didasari kesadaran bersama dalam menanggulangi permasalahan yang dapat mengganggu keamanan dan ketertiban masyarakat guna menciptakan rasa aman, tertib dan tentram serta meningkatkan kualitas kehidupan masyarakat. Upaya menanggulangi permasalahan yang dapat mengganggu keamanan, ketertiban dan ketentraman masyarakat yang mencakup rangkaian upaya pencegahan dengan melakukan identifikasi akar permasalahan, menganalisis, menetapkan perioritas tindakan, melakukan evaluasi dan evaluasi ulang atas efektifitas tindakan.

Morgan dan Hunt dalam (Akbar dan Parvez,2009:26) "stated that trust exist only when one party has confidence in an exchange partner's reliability andintegrity" menyatakan bahwa kepercayaan hanya ada ketika salah satu pihak yakin dalam hubungan kerjasama yang dapat diandalkan dan mempunyai integritas. Barnes (2003:148) kepercayaan adalah keyakinan bahwa seseorang akan menemukan apa yang ia inginkan pada diri orang lain, dan bukan apa yang iatakutkan. Kepercayaan melibatkan kesediaan seseoranguntuk bertingkah laku tertentu karena keyakinan bahwa partnernya akan memberikan kepuasan yang ia harapkan dan suatu harapan yang umumnya dimiliki seseorang bahwa kata, janji,atau pernyataan orang lain dapat dipercaya. Morgan et al. (dalam Akbar dan Parvez, 2009) menjelaskan beberapa manfaat dari adanya kepercayaan:

1. Kepercayaan dapat mendorong pemasar untuk berusaha menjaga hubungan yang terjalin dengan bekerjasama dengan rekan perdagangan.

2. Kepercayan menolak pilihan jangka pendek dan lebih memilih keuntungan jangka panjang yang diharapkan dengan mempertahankan rekan yang ada. 
3. Kepercayaan dapat mendorong pemasar untuk mendatangkan risiko besar dengan bijaksana karena percaya bahwa rekannya tidak akan mengambil kesempatan yang dapat merugikan pasar.

Menurut (Agus : 2012:25) tanggung jawab adalah"orang yang bisa melakukan control internal sekaligus bahwa suatu kenyakinan bahwa ia boleh mengontrol dirinya dan yakin bahwa kesuksesan yang dicapainya adalah hasil usahanya sendiri".

Macam-macam Tanggungjawab. Menurut Mustari(2011:26) macam-macam tanggung jawab antara lain:

1. Tanggung jawab Personal

Tanggung Jawab adalah sikap dan perilaku seseorang untuk melaksanakan tugas dan kewajiban yang seharusnya dilakukan terhadap diri sendiri, masyarakat, lingkungan (alam, sosial dan budaya), negara, dan Tuhan Yang Maha Esa.

2. Tanggung jawab Moral

Tanggung jawab moral biasanya merujuk ada pemikiran bahwa seseorang mempunyai kewajiban moral dalam situasi tertentu. Orang yang tidak taat terhadap kewajibankewajiban moral kemudian menjadi alasan untuk diberikan hukuman.

3. Tanggung jawab Sosial

Tanggung jawab social adalah tanggung jawab dimana manusia saling memberikan dan tidak membuat kerugian kepada masyarakat yang lain, selain itu tanggung jawab social adalah Tanggung jawab yang merupakan sifat-sifat yang perlu di kendali kan dalam hubungannya dengan orang lain.

Untuk mendukung tugas pokok tersebut di atas, polisi juga memiliki tugas-tugas tertentu sebagaimana tercantum dalam Pasal 14 ayat (1)Undang-Undang No. 2 Tahun 2002 tentang Kepolisian Negara Republik Indonesia adalah sebagai berikut:

1. Melaksanakan pengaturan penjagaan, pengawalan, dan patrol terhadap kegiatan masyarakat dan pemerintah sesuai kebutuhan.

2. Menyelenggarakan segala kegiatan dalam menjamin keamanan,ketertiban dan kelancaran lalu lintas di jalan.

3. Membina masyarakat untuk meningkatkan partisipasi masyarakat, kesadaran hukum masyarakat, serta ketaatan warga masyaraka terhadap hukum dan peraturan perundangundangan.

4. Turut serta dalam pembinaan hukum nasional.

5. Memelihara ketertiban dan menjamin keamanan umum: melakukan koordinasi, pengawasan, dan pembinaan teknis terhadap kepolisian khusus, penyidik pegawai negeri sipildan bentuk-bentuk pengamanan swakarsa.

6. Melakukan koordinasi, pengawasan, dan pembinaan teknis terhadap kepolisian khusus, penyidik pegawai negeri sipil dan bentuk - bentuk pengamanan swakarsa.

7. Melakukan penyelidikan terhadap semua tindak pidana sesuai dengan hukum acara pidana dan peraturan perundang-undangan lainnya.

8. Menyelenggarakan identifikasi kepolisian, kedokteran kepolisian, laboratorium forensik dan psikologi kepolisian untuk kepentingan tugas kepolisian.

9. Melindungi keselamatan jiwa raga, harta benda, masyarakat dan lingkungan hidup dari gangguan ketertiban dan / atau bencana termasuk memberikan bantuan dan pertolongan dengan menjunjung tinggi hak asasi manusia.

10. Melayani kepentingan warga masyarakat untuk sementara sebelum ditangani oleh instansi/ atau pihak berwenang.

11. Memberikan pelayanan kepada masyarakat sesuai dengan kepentingan dalam lingkup tugas kepolisian. 
12. Melaksanakan tugas lain sesuai dengan peraturan perundang-undangan.

Walgito (2002) mendefinisikan sikap adalah organisasi pendapat, keyakinan seseorang mengenai objek atau situasi yang sering terjadi, disertai adanya perasaan tertentu dan memberikan dasar kepada orang tersebut untuk membuat respons atau berperilaku dalam cara yang tertentu sesuai dengan pilihannya. Faktor-faktor yang dapat mempengaruhi pembentukan sikap (Azwar,2003) adalah:

1. Pengalaman pribadi ; Sikap akan lebih mudah terbentuk apabila pengalaman pribadi terjadi dalam situasi yang melibatkan faktor emosional.

2. Pengaruh orang lain yang dianggap penting ; Pada umumnya, individu cenderung untuk memiliki sikap yang konformis atau searah dengan sikap orang yang dianggap penting. Kecenderungan ini dimotivasi oleh keinginan untuk berafiliasi dan keinginan untuk menghindari konflik dengan orang yang dianggap penting.

Menurut Supranto (1997: 23), kepuasan adalah tingkat perasaan seseorang setelah membandingkan kinerja atau hasil yang dirasakan dengan harapannya. Kepuasan masyarakat merupakan perasaan senang atau kecewa sebagai hasil dariperbandingan antara prestasi atau produk yang dirasakan dan diharapkan.

Menurut Lupiyoadi (2006: 155), faktor utama penentu kepuasan masyarakat adalah persepsi terhadap kualitas jasa. Apabila ditinjau lebih jauh, pencapaian kepuasan masyarakat melalui kualitas pelayanan dapat ditingkatkan dengan beberapa pendekatan sebagai berikut:

1. Memperkecil kesenjangan yang terjadi antara pihak manajemen dengan pihak masyarakat.

2. Organisasi publik harus mampu membangun komitmen bersama untuk menciptakan visi di dalam perbaikan proses pelayanan.

3. Memberikan kesempatan pada masyarakat untuk menyampaikan keluhan dengan membentuk sistem saran dan kritik.

4. Mengembangkan pelayanan untuk mencapai kepuasan dan harapan masyarakat Berdasarkan beberapa pengertian di atas maka terdapat kesamaan definisi mengenai kepuasan, yaitu yang menyangkut komponen kepuasan (harapan dan kinerja hasil yang dirasakan). Umumnya harapan merupakan perkiraan atau keyakinan masyarakat tentang apa yang akan diterimanya bila ia membeli atau mengkonsumsi suatu produk (barang dan jasa). Sedangkan kinerja yang dirasakan adalah persepsi terhadap apa yang ia terima setelah mengkonsumsi produk yangdibeli dan untuk menciptakan kepuasan masyarakat, organisasi publik harus menciptakan dan mengelola sistem untuk memperoleh pelangan yang lebih banyak dan kemampuan mempertahankan masyarakat.

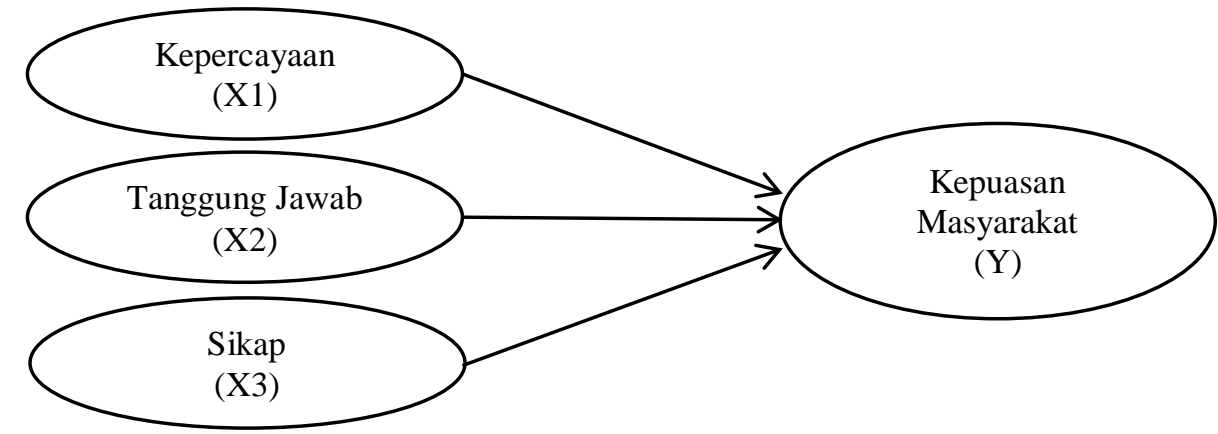

Gambar 1. Model Kerangka Konseptual Penelitian 
Berdasarkan kajian teoritis yag dilengkapi juga dengan kerangka konseptual pada Gambar 1, ditentukan hipotesis yang akan diuji dalam penelitian ini adalah :

1. Kepercayaan berpengaruh secara Parsial terhadap Kepuasan masyarakat Unit Pembinaan Masyarakat Polsek Dusun Timur Kabupaten Barito Timur.

2. Tanggungjawab berpengaruh secara parsial Terhadap Kepuasan Masyarakat Unit Pembinaan Masyarakat Polsek Dusun Timur Kabupaten Barito Timur.

3. Sikap berpengaruh secara parsial Terhadap Kepuasan Masyarakat Unit Pembinaan Masyarakat Polsek Dusun Timur Kabupaten Barito Timur

4. Kepercayaan, Tanggungjawab dan Sikap berpengaruh secara Simultan Terhadap Kepuasan Masyarakat Unit Pembinaan Masyarakat Polsek Dusun Timur Kabupaten Barito Timur.

5. Variabel Kepercayaan secara dominan berpengaruh terhadap Kepuasan Masyarakat Unit Pembinaan Masyarakat Polsek Dusun Timur Kabupaten Barito Timur.

\section{Metode Penelitian}

Penelitian ini berdasarkan desain Kuantitatif menggunakan Teknik Analisis regresi berganda yang dibantu dengan Program SPSS 17.0. Dalam penelitian ini populasinya adalah masyarakat yang kurang lebih berjumlah 7.000 orang, yang diwakili oleh 3 (tiga) orang yang terdiri dari Kepala Desa, Sekretaris Desa, dan Ketua Badan Permusyawaratan Desa (BPD). Di wilayah Polsek Dusun Timur terdiri dari 25(Dua Puluh Lima) desa dan 1 (satu) kelurahan, maka jumlah populasi 26 × $3=78$ orang. Definisi operasional variabel mengubah konsep atau variabel yang abtrak ketingkat yang lebih realistis, kongkrit, sehingga gejala tersebut mudah dikenal. berikut:

Adapun definisi operasional variabel yang berhubungan dengan penelitian ini adalah

1. Variabel Kepercayaan (X1)

Indikator-indikator Kepercayaan Konsumen Gefen (dalam Yee dan faziharudean, 2010) menyatakan bahwa indikator kepercayaan terdiri dari 3 komponen, yaitu :

a. Integritas (Integrity)

Merupakan persepsi konsumen bahwa perusahaan mengikuti prinsip-prinsip yang dapat diterima seperti menepati janji, berperilaku sesuai etika dan jujur. Integritas perusahaan tergantung dari konsistensi perusahaan dimasa lalu, komunikasi kredibel atau komunikasi tidak kredibel suatu perusahaan pada kelompok lain, dan apakah tindakan yang dilakukan perusahaan sesuai dengan janji atau kata-kata yang diucapkan perusahaan.

b. Kebaikan (Benevolence)

Yang didasarkan pada besarnya kepercayaan kemitraan yang memiliki tujuan dan motivasi yang menjadi kelebihan untuk organisasi lain pada saat kondisi yang baru muncul, yaitu kondisi dimana komitmen tidak terbentuk.

c. Kompetensi (Competence)

Kompetensi merupakan kemampuan untuk memecahkan permasalahan yangdihadapi oleh konsumen dan memenuhi segala keperluannya. Kemampuan mengacu pada keahlian dan karakteristik yang memungkinkan suatu kelompok mempunyai pengaruh yang dominan.

2. Variabel Tanggungjawab (X2)

Indikator yang digunakan untuk mengukur tanggungjawab adalah :

a. Kemampuan seseorang untuk menjalankan kewajiban karena dorongan di dalam dirinya atau bisa disebut dengan panggilan jiwa. 
b. Orang yang melaksanakan segala sesuatu atau pekerjaan dengan sungguh- sungguh dengan sukarela.

c. Berani menanggung segala resiko dan segala sesuatunya baik dari perkataan, perbuatan dan sikap.

3. Variabel Sikap (X3)

Sikap adalah penilaian positif atau negatif individu terhadap suatu objek yang merupakan kombinasi dari reaksi kognitif, afektif dan konatif ( menurut Azwar, 2003). Indikator yang digunakan untuk mengukur Sikap adalah:

a. Bentuk evaluasi atau reaksi perasaan.

b. Semacam kesiapan untuk bereaksi terhadap suatau objek dengan caraTertentu.

c. Konstelasi komponen - komponen kogniitif, afektif, dan konatif yang saling berinteraksi dalam memahami, merasakan, dan berperilaku terhadap suatu objek.

d. Kombinasi reaksi kognitif, afektif dan konatif terhadap suatu objek.

e. Sikap atau penilaian positif atau negatif terhadap suatu objek.

4. Variabel Kepuasan Masyarakat (Y)

Indikator yang digunakan untuk mengukur kepuasan masyarakat adalah :

1. Kualitas produk/jasa, publik akan puas bila hasil evaluasi menunjukkan bahwa produk/jasa berkualitas.

2. Kualitas pelayanan, publik akan puas bila mendapatkan pelayanan yang baik atau yang sesuai dengan yang diharapkan.

3. Emosional, publik akan bangga dan mendapatkan keyakinan bila menggunakan produk/jasa dengan merek tertentu yang cendrung mempunyai tingkat kepuasan yang lebih tinggi.

4. Harga, produk kualitas yang sama tetapi mempunyai harga yang lebih murah akan memberikan nilai yang lebih tinggi.

5. Biaya, publik tidak perlu biaya tambahan tidak perlu membuang waktu untuk mendapatkan barang atau jasa yang diinginkan.

\section{Hasil Penelitian dan Pembahasan}

Mengingat penelitian ini bertujuan untuk mengkaji bagaimana Kepercayaan, Tanggungjawab dan Sikap terhadap Kepuasan Masyarakat Unit Pembinaan Masyarakat Polsek Dusun Timur Kabupaten Barito Timur, untuk itu perlu diketahui karakteristik responden yang menjadi sampel dan sumber data dalam penelitian ini.

Tabel 1. Karakteristik Responden Menurut Jenis Kelamin

\begin{tabular}{llccr}
\hline No & Jenis Kelamin & Frequency & Valid Percent & Comulative Percent \\
\hline 1. & Laki-laki & 68 & 87.2 & 87.2 \\
2. & Perempuan & 10 & 12.8 & \\
\cline { 1 - 3 } & Jumlah & 78 & 100.0 & \\
\hline
\end{tabular}

Tabel 2. Jumlah Responden Menurut Pendidikan

\begin{tabular}{|c|c|c|c|c|c|}
\hline \multicolumn{2}{|c|}{ Pendidikan } & Frequency & Percent & Valid Percent & Cumulative Percent \\
\hline \multirow[t]{6}{*}{ Valid } & $\mathrm{SD}$ & 1 & 1.3 & 1.3 & 1.3 \\
\hline & SMP & 10 & 12.8 & 12.8 & 14.1 \\
\hline & SLTA & 50 & 64.1 & 64.1 & 78.2 \\
\hline & D3 & 8 & 10.3 & 10.3 & 88.5 \\
\hline & S1 & 9 & 11.5 & 11.5 & 100.0 \\
\hline & Jumlah & 78 & 100.0 & 100.0 & \\
\hline & & & & $\begin{array}{r}\text { JIEB, Jil } \\
\text { IS }\end{array}$ & $\begin{array}{l}\text { 4, No 2, Juli } 2018 \\
\text { Online 2615-2134 }\end{array}$ \\
\hline
\end{tabular}


Berdasarkan tabel 2 dapat dilihat jumlah responden yang berpendidikan S-1 sebanyak 9 orang atau sebesar $11.5 \%$,yang berpendidikan D3 sebanyak 8 orang atau sebesar $10.3 \%$, yang berpendidikan SLTA sebanyak 50 orang atau sebesar 64.1\%. yang berpendidikan SMP sebanyak 10 orang atau sebesar $12.8 \%$ dan yang berpendidikan SD sebanyak 1 orang atau sebesar $1.3 \%$. Dengan demikian dapat diketahui mayoritas responden penelitian pada Polsek Dusun Timur adalah mereka yang berpendidikan SLTA.

Setelah dinyatakan lolos uji validitas dan reliabilitas, maka dilakukan uji asumsi klasik untuk melihat kualitas dari model yang dihasilkan, yang terdiri dari:

1. Uji Multikolinearitas

Tabel 3. Hasil Uji Multikolinearitas

\begin{tabular}{lllll}
\hline \multirow{2}{*}{ Model } & Sig. & \multicolumn{2}{c}{ Collinearity Statistics } \\
\cline { 3 - 5 } & & & Tolerance & VIF \\
\hline \multirow{2}{*}{1} & (Constant) & .273 & & \\
\cline { 2 - 5 } & Kepercayaan & .128 & .573 & 1.744 \\
\cline { 2 - 5 } & Tanggung Jawab & .231 & .737 & 1.356 \\
\cline { 2 - 5 } & Sikap & .000 & .640 & 1.562 \\
\hline
\end{tabular}

Karena ketiga Variabel bebas memiliki nilai VIF dibawah 5, maka dapat dikatakan bahwa model penelitian ini bebas masalah multikolinearitas.

2. Uji Heterokedastisitas

Hasil perhitungan residual dan scatterplot diagram tidak ditemukan adanya pola tertentu seperti bergelombang, melebar dan menyempit. Karena data pada scatterplot menyebar secara acak, maka dapat dikatakan bahwa penelitian ini bebas masalah heterokedastisitas.

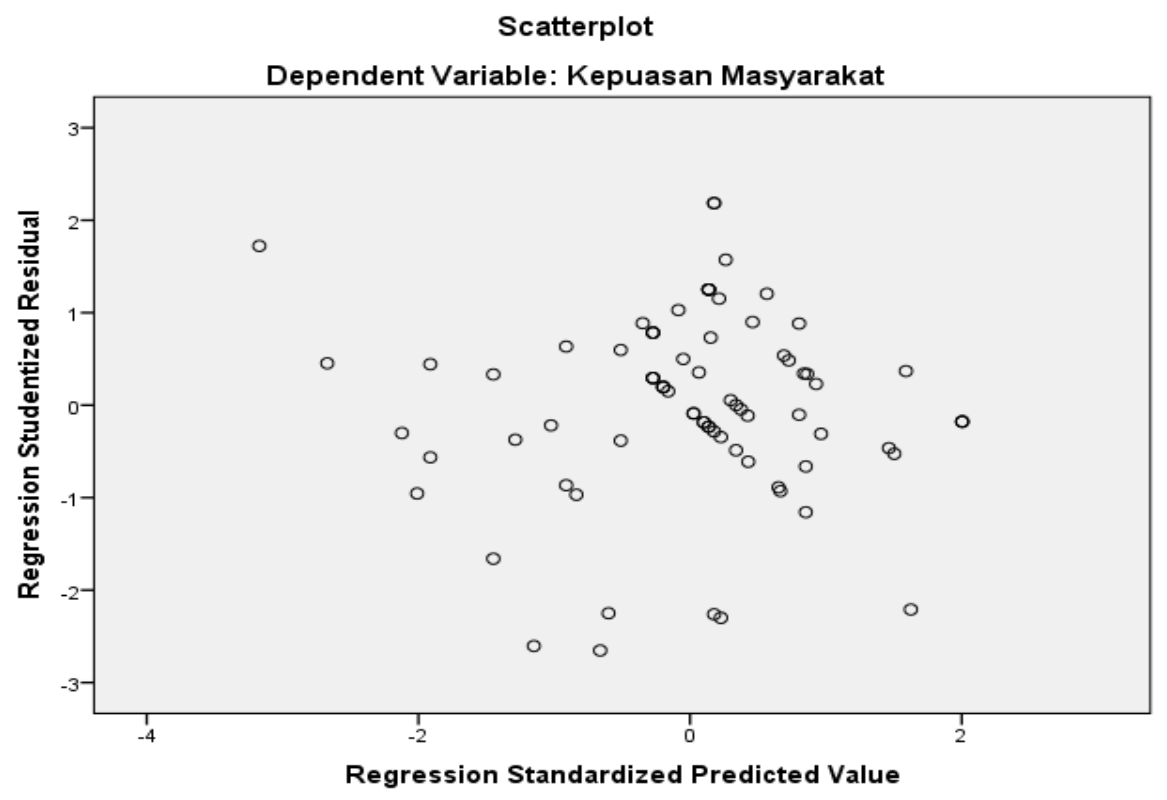

Gambar 2. Diagram Uji Asumsi Heteroskedastisitas

3. Uji Normalitas

Karena data pada Normal P-P Plot berada di sekitar garis normal, maka dapat dikatakan bahwa residual data penelitian ini terdistribusi secara normal (lihat Gambar 3). 


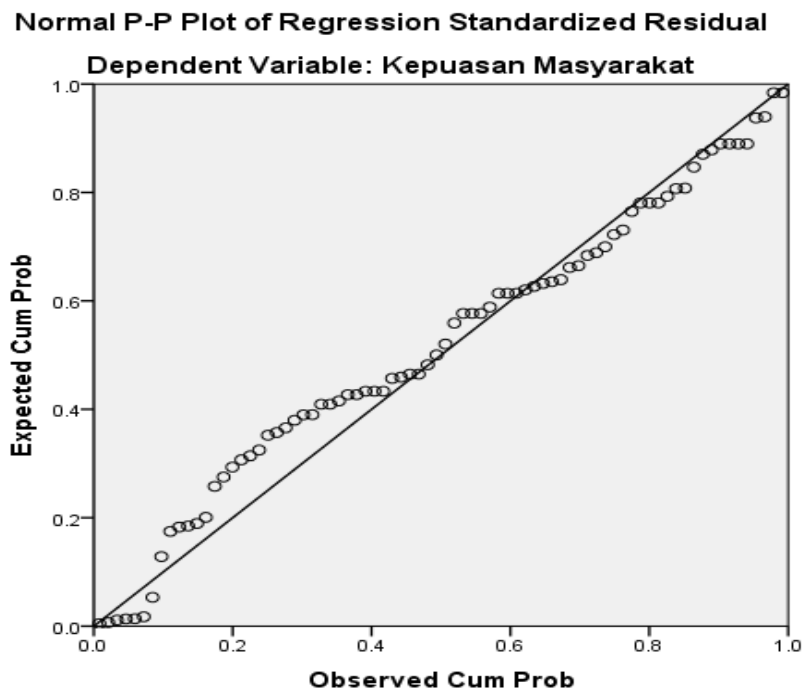

Gambar 3 : Diagram Uji Normalitas

Setelah model penelitian ini dinyatakan lolos uji asumsi klasik, maka langkah selanjutnya adalah pengujian hipotesis. Pengujian hipoesis dilakukan melalui analisis regresi linear berganda, atau lebih tepatnya uji $\mathrm{F}$ dan uji $\mathrm{t}$.

1. Uji F (simultan)

\section{Tabel 4. Hasil Uji Simultan (uji F)}

\begin{tabular}{|c|c|c|c|c|c|c|}
\hline \multicolumn{7}{|c|}{ ANOVA $^{\mathrm{a}}$} \\
\hline \multicolumn{2}{|c|}{ Model } & \multirow{2}{*}{$\begin{array}{c}\begin{array}{c}\text { Sum of } \\
\text { Squares }\end{array} \\
524.966\end{array}$} & \multirow{2}{*}{$\begin{array}{r}\text { df } \\
3\end{array}$} & \multirow{2}{*}{$\begin{array}{l}\text { Mean } \\
\text { Square } \\
174.989\end{array}$} & \multirow{2}{*}{$\begin{array}{l}\mathrm{F} \\
41.109 \\
\end{array}$} & \multirow{2}{*}{$\begin{array}{l}\text { Sig. } \\
.000^{b}\end{array}$} \\
\hline \multirow[t]{3}{*}{1} & Regression & & & & & \\
\hline & Residual & 314.995 & 74 & 4.257 & & \\
\hline & Total & 839.962 & 77 & & & \\
\hline \multicolumn{7}{|c|}{$\begin{array}{l}\text { Sumber : Hasil Uji dengan SPSS } \\
\text { a. Dependent Variable: Kepuasan Masyarakat }\end{array}$} \\
\hline
\end{tabular}

Karena nilai signifikansinya $<0,05$, jadi dapat dikatakan bahwa $\mathrm{X} 1, \mathrm{X} 2$, dan $\mathrm{X} 3$ berpengaruh secara simultan terhadap Y.

Tabel 5. Model Summary ${ }^{b}$

\begin{tabular}{lcccr}
\hline Model & R & R Square & $\begin{array}{c}\text { Adjusted R } \\
\text { Square }\end{array}$ & Std. Error of the Estimate \\
\hline 1 & $.791^{\mathrm{a}}$ & .625 & $\mathbf{. 6 1 0}$ & 2.06318 \\
\hline Sumber : Hasil Uji dengan SPSS & & \\
Predictors: (Constant), Sikap, Tanggung Jawab, Kepercayaan & \\
\hline
\end{tabular}

Berdasarkan dari output diatas SPSS, besarnya Adjusted R2 square adalah 0,610 atau 61\% hal ini berarti variasi variabel terikat bisa dijelaskan oleh variasi dari ketiga variabel bebas yang diambil dalam penelitian ini. R2 Square sebesar 0,610 bahwa kontribusi ketiga variabel bebas terhadap kinerja personil Polsek Dusun Timur Kabupaten Barito Timur adalah sebesar $61 \% \%$, sedangkan sisanya sebesar $39 \%$ adalah sumbangan dari faktor lain 
yang tidak diketahui dalam penelitian ini atau tidak dilakukan penelitian dalam obyek penelitian ini.

2. Uji t (parsial)

Tabel 6. Uji Parsial (uji t)

\begin{tabular}{|c|c|c|c|c|c|c|}
\hline \multicolumn{2}{|c|}{ Model } & \multicolumn{2}{|c|}{$\begin{array}{c}\text { Unstandardized } \\
\text { Coefficients }\end{array}$} & \multirow{2}{*}{$\begin{array}{c}\text { Standardized } \\
\text { Coefficients } \\
\text { Beta }\end{array}$} & \multirow[t]{2}{*}{$\mathrm{t}$} & \multirow[t]{2}{*}{ Sig. } \\
\hline & & B & Std. Error & & & \\
\hline \multirow[t]{4}{*}{1} & (Constant) & -2.400 & 2.172 & & -1.105 & .273 \\
\hline & Kepercayaan & .291 & .189 & .145 & 1.541 & .128 \\
\hline & Tanggung Jawab & .198 & .164 & .100 & 1.208 & .231 \\
\hline & Sikap & .817 & .112 & .647 & 7.269 & .000 \\
\hline
\end{tabular}

Hasil pengujian secara parsial adalah sebagai berikut:

- X1: Kepercayaan tidak berpengaruh signifikan terhadap Y: Kepuasan Masyarakat

- X2: Tanggung Jawab tidak berpengaruh signifikan terhadap Y: Kepuasan Masyarakat

- X3: Sikap berpengaruh signifikan terhadap Y: Kepuasan Masyarakat

Jadi Fungsi regresinya adalah sebagai berikut :

$\mathrm{Y}=-2.400+0,291 \mathrm{X} 1+0,198 \mathrm{X} 2+0,817 \mathrm{X} 3+\mathrm{e}$

Karena variabel yang signfikan hanya X3 : Sikap, maka variabel yang dominan jelas adalah X3 : Sikap.

.Pada pengujian dengan uji t diketahui bahwa variabel bebas yaitu Kepercayaan (X1) dan Tanggungjawab (X2) secara parsial tidak berpengaruh terhadap Kepuasan Masyarakat (Y) Unit Pembinaan Masyarakat Polsek Dusun Timur Kabupaten Barito Timur. Secara parsial hanya variabel Sikap (X3) yang berpengaruh kuat terhadap Kepuasan Masyarakat (Y) Unit Pembinaan Masyarakat Polsek Dusun Timur Kabupaten Barito Timur. Ketiga variabel bebas secara simultan berpengaruh signiikan terhadap variabel Kepuasan Masyarakat (Y). Dari hasil penelitian koefisien korelasi parsial dimana didapatkan bahwa variabel Lingkungan Kerja (X3) merupakan variabel bebas yang dominan mempengaruhi variabel terikat yaitu Kepuasan Masyarakat Unit Pembinaan Masyarakat Polsek Dusun Timur Kabupaten Barito Timur.

Dari hasil yang didapat bahwa Sikap menunjukkan pengaruh yang kuat terhadap Kepuasan Masyarakat. Hal ini menunjukkan bahwa dengan bentuk evaluasi atau reaksi perasaan, kesiapan untuk bereaksi terhadap suatau objek dengan caraTertentu, konstelasi komponen - komponen kogniitif, afektif, dan nonatif yang saling berinteraksi dalam memahami, merasakan, dan berperilaku terhadap suatu objek, sikap atau penilaian positif atau negatif terhadap suatu objek yang diterjadi pada Masyarakat Unit Pelayanan Masyarakat Polsek Dusun Timur Kabupaten Barito Timur diterapkan dengan baik, akan mampu meningkatkan Kepuasan masyarakat unit pembinaan masyarakat Polsek Dusun Timur Kabupaten Barito Timur.

\section{Kesimpulan}

Dari hasil pengujian yang telah dilakukan, maka dapat dirumuskan serangkaian kesimpulan sebagai berikut:

1. Variabel X1: Kepercayaan dan X2 : Tanggung Jawab secara parsial tidak berpengaruh signifikan terhadap Y: Kepuasan Masyarakat. 
2. Variabel X3: Sikap secara parsial berpengaruh signifikan terhadap Y: Kepuasan Masyarakat.

3. Variabel Kepercayaan (X1), Tanggungjawab (X2), dan variabel Sikap ( X3) berpengaruh secara simultan terhadap variabel Kepuasan Masyarakat (Y). Hal ini ditunjukkan dengan Nilai Adjusted R Square sebesar 0,610 atau 61\% menunjukkan bahwa perubahan pada Y $61 \%$ disebabkan oleh variabel Kepercayaan (X1), variabel Tanggungjawab (X2), dan variabel Sikap (X3), sedangkan sisanya 39\% oleh faktor lain.

4. Terujinya hipotesis secara parsial hanya variabel X3 yaitu sikap yang berpengaruh terhadap Kepuasan Masyarakat (Y) Unit Pembinaan Masyarakat Polsek Dusun Timur Kabupaten Barito Timur, sehingga dapat disimpulkan bahwa kepuasan masyarakat hanya dipengaruhi oleh sikap (X3) dengan menganggap variabel lain tetap, maka variabel yang dominan adalah variabel X3 yaitu Sikap.

Adapun saran yang direkomendasikan adalah sebagai berikut :

1. Untuk meningkatkan kepuasan masyarakat unit pembinaan masyarakat Polsek Dusun Timur Kabupaten Barito Timur, agar kiranya selalu meningkatkan kepercayaan, tanggungjawab yang baik dalam pekerjaan dan tugas serta memperhatikan sikap. Hal ini perlu disadari bahwa ketiga variabel yaitu kepercayaan, tanggungjawab dan sikap sangat mendukung dan meningkatkan tingkat kepuasan masyarakat.

2. Mutu layanan yang sudah baik perlu dipertahankan dengan terus konsisten untuk memberikan pelayanan yang terbaik untuk masyarakat. Disini yang masih perlu ditingkatkan yaitu Sikap dari para pegawai yaitu mampu memberikan pelayanan secara tuntas, artinya ketika melayani masyarakat, anggota babinkantibmas harus menunjukkan sikap yang baik, santun dan kepercayaan, serta tanggungjawab dari para anggota yang bersangkutan harus dapat menyelesaiakannya sampai selesai dan tidak melimpahkannya ke anggota lainnya sehingga tidak membuat masyarakat merasa dipersulit.

3. Saran terhadap penelitian mendatang. Bagi peneliti mendatang disarankan untuk melakukan penelitian dengan menggunakan obyek penelitian pelayanan masyarakat lainnya. Hasil yang didapat bisa menjadi perbandingan dengan penelitian yang dilakukan ini, khususnya dalam hal unsur - unsur pelayanan yang berpengaruh signifikan terhadap kepuasan masyarakat di dalam mendapatkan pelayanan.

\section{DAFTAR PUSTAKA}

Amran, 2009, Pengaruh Disiplin Kerja Terhadap Kinerja Pegawai Kantor Departemen Sosial Kabupaten Gorontalo,Jurnal Ichsan Gorontalo,vol. 4, no. 2.

Artina, H.B. Isyandi ; 2014; Pengaruh Kepemimpinan, Budaya Kerja, Ligkungan Kerja Terhadap Disiplin Kerja Dan Kinerja Personil Polda Riau. Tesis

Dessler, Gary. 2012. Manajemen Sumber Daya Manusia. Edisi Kesepuluh. Jilid 2. Jakarta : PT. Indeks.

Diah Indriani Suwondo; Eddy Madiono Sutanto; 2015; Pengaruh Lingkungan Kerja, Disiplin Kerja Terhadap Kinerja Karyawan; JMK, Vol. 17, No. 2, September 2015,135-144

Gomes, Faustino Cardoso. 2015. Manajemen Sumber Daya Manusia. Penerbit Andi ; Yogyakarta

Gouzali Saydam. (2005). Manajemen Sumber daya Manusia: Suatu pendekatan Mikro. Jakarta: Djambaran.

Hasibuan, H. Malayu, S.P. 2012, Manajemen, (Dasar, Pengertian, dan Masalah). Edisi revisi, Jakarta : Bumi Aksara.

Hasibuan, Malayu S.P. 2012. Manajemen Sumber Daya Manusia. Jakarta: PT Bumi Aksara Husein Umar, Metedologi Penelitian untuk Skripsi dan Tesis Bisnis, Jakarta : PT. Raja Grafindo Persada, 2008 
Ismail (2004) Manajemen Sumber Daya Manusia, Ed. Revisi, Jakarta, PT. Bumi Aksara Komarudin, 2001, Ensiklopedia Manajemen, Edisi IX, Jakarta : Bumi Aksara.

Komang Ayu Astini, 2015, Pengaruh Penempatan Kerja, Lingkungan Kerja, Pengawasan Terhadap Disiplin Kerja Personil Polda Bali; Skripsi

Mangkunegara, Anwar Prabu. 2012, Manajemen Sumber Daya Manusia, Bandung : Remaja Rusdakarya.

Mardiana. 2005. ManajemenProduksi. Jakarta: IPWI

Marwansyah dan Mukaram (2014), Manajemen Sumber Daya Manusia,

Moenir,2015,,Pendekatan Manusiawi dan Organisasi terhadap Pembinaan Kepegawaian, Gunung Agung, Jakarta.

Momo Kelana, "Membangun Budaya Polisi Indonesia", www.polri.id

Mondy R Wayne, (2015) : Manajemen Sumber Daya Manusia, Jakarta : Erlangga.

Nurhaida , Novita (2015); Teori-teori Manajemen dan Organisasi,Jakarta, PT. Bumi Aksara

Render, Barry dan Heizer, Jay. 2008. Operation Management, Jilid kedua edisi ketujuh, Jakarta: Salemba Empat

Rivai, Veithzal, Dato' Ahmad Fawzi, Mohd. Basri. 2010 Performance Appraisal, sistem yang tepat untuk menilai kinerja karyawan dan meningkatkan daya saing perusahaan. Jakarta: Pt. Raja Grafindo Persada.

Rivai Veithzal, 2011. Manajemen Sumber Daya untuk Perusahaan, PT. Rajagrafindo Persada, Jakarta.

Robbins, Stephen P. 2007. Perilaku Organisasi. PT Indeks.

Robbins, Stephen, 2001, SPSS Statistik Multivariast PT Elex Komputindo, Kelompok Gramedia, Jakarta.

Sarwono, S.W \& Meinarno, E.A. (2009). Psikologi Sosial.Jakarta:Salemba Humanika.

Sedarmayanti. (2009).Manajemen Sumber Daya Manusia, Reformasi Birokrasi dan Manajemen Pegallwai Negeri Sipil (cetakan kelima). Bandung : PT Refika Aditama

Simamora, Bilson.2010.Penilaian Kinerja dalam Manajemen Perusahaan. Jakarta : Gramedia Pustaka.

Siagian P. Sondang. 2004. Teori motivasi dan Aplikasinya. Edisi 3. Jakarta: PT.Rineka Cipta.

Siagian P. Sondang. 1992. Manajemen Sumber Daya Manusia. Jakarta: Penerbit Bumi Aksara.

Simamora, H. 2004, Manajemen Sumber Daya Manusia Edisi Ketiga Yogyakarta Sekolah Tinggi Ilmu Ekonomi YKPN.

Soeprihanto, Jhon, 2007, Penilaian Kinerja Dan Pengembangan Karyawan PT PBFE Yogyakarta.

Soerjono Soekanto, "Faktor-Faktor Yang Mempengaruhi Penegakan Hukum", Jakarta, Raja Press, 2002, hal.55

Sutrisno, Edy. 2013. Manajemen Sumber Daya Manusia . Jakarta: Kencana Prenada Media Group 